\title{
A Review on Biomass Classification and Composition, Co-Firing Issues and Pretreatment Methods
}

\section{ASABE Annual International Meeting}

Jaya Shankar Tumuluru

Shahab Sokhansanj Christopher T. Wright

Richard D. Boardman

Neal A. Yancey

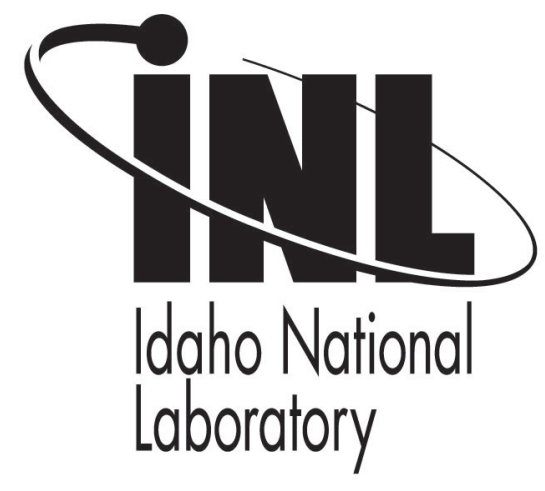

\section{August 2011}

This is a preprint of a paper intended for publication in a journal or proceedings. Since changes may be made before publication, this preprint should not be cited or reproduced without permission of the author. This document was prepared as an account of work sponsored by an agency of the United States Government. Neither the United States Government nor any agency thereof, or any of their employees, makes any warranty, expressed or implied, or assumes any legal liability or responsibility for any third party's use, or the results of such use, of any information, apparatus, product or process disclosed in this report, or represents that its use by such third party would not infringe privately owned rights. The views expressed in this paper are not necessarily those of the United States Government or the sponsoring agency. 


\title{
A Review on Biomass Classification and Composition, Co-firing Issues and Pretreatment Methods
}

\author{
Jaya Shankar Tumuluru ${ }^{* 1}$, Shahab Sokhansanj ${ }^{2}$, Christopher T. Wright ${ }^{1}$, Richard D. \\ Boardman $^{1}$ and Neal A. Yancey ${ }^{1}$ \\ ${ }^{1}$ Idaho National Laboratory, 2525 North Fremont Ave., Idaho Falls Idaho 83415. \\ JayaShankar.tumuluru@inl.gov . \\ ${ }^{2}$ Oakridge National Laboratory, Environmental Sciences Division, Oak Ridge, TN 37831-6422 \\ sokhansanjs@ornl.gov. \\ Written for presentation at the \\ 2011 ASABE Annual International Meeting \\ Sponsored by ASABE \\ Gault House \\ Louisville, Kentucky \\ August $7-10,2011$
}

\begin{abstract}
Presently, around the globe, there is a significant interest in using biomass for power generation as power generation from coal continues to raise environmental concerns. Using just biomass for power generation can bring a lot of environmental benefits. However the constraints of using biomass alone can include high investments costs for biomass feed systems and also uncertainty in the security of the feedstock supply due to seasonal variations, and in most countries, limited infrastructure for biomass supply. Alternatively, co-firing biomass along with coal offers advantages like a) reducing the issues related to biomass quality and buffers the system when there is insufficient feedstock quantity and b) costs of adapting the existing coal power plants will be lower than building new systems dedicated only to biomass. However, with the above said advantages there exists some technical constrains including low heating and energy density values, low bulk density, lower grindability index, higher moisture and ash content. In order to successfully cofire biomass with coal, biomass feedstock specifications need to be established to direct pretreatment options that may include increasing the energy density, bulk density, stability during storage and grindability. Impacts on particle transport systems, flame stability, pollutant formation and boiler tube fouling/corrosion must also be minimized by setting feedstock specifications including composition and blend ratios if necessary. Some of these limitations can be overcome by using preprocessing methods. This paper discusses the impact of feedstock preprocessing methods like sizing, baling, pelletizing, briquetting, washing/leaching,
\end{abstract}


torrefaction, torrefaction and pelletization and steam explosion in attainment of optimum feedstock characteristics to successfully cofire biomass with coal.

Key Words: Biomass, co-firing issues, pretreatment methods, physical and chemical properties 


\section{Introduction}

Behind only coal and oil, biomass stands as the third-largest energy resource in the world (Bapat et al. 1997). Until the mid-19th century, biomass dominated global energy consumption. With steep increases in fossil-fuel usage, biomass consumption for energy purposes has declined for the past 50 years, but still provides about 1.25 billion tons of oil equivalents (Btoe) or about $14 \%$ of the world's annual energy consumption (Purohit et al., 2006; Werther et al., 2000; and Zeng et al., 2007). Out of the 230 exajoules of estimated global primary energy, 56 exajoules-nearly one-fourth-is used for agricultural practices (WEC, 1994). Wood fuels, agricultural straws, and grasses are the most prominent biomass energy sources.

Biomass, if properly managed, offers many advantages, the most important being a renewable and sustainable energy feedstock. It can significantly reduce net carbon emissions when compared with fossil fuels, making it a clean development mechanism (CDM) for reducing greenhouse gas (GHG) emissions ( $\mathrm{Li}$ and $\mathrm{Hu}, 2003$ ). The cheapest biomass sources are the waste products from wood or agro-processing operations, but their supply is limited. To overcome this limitation, countries around the world are planting biomass crops for energy purposes. Most developed and industrialized nations have begun developing technologies to use biomass more efficiently. In the United States and most of Europe, biomass has already penetrated the energy market. The United States and Sweden obtain about 4 and $13 \%$ of their energy, respectively, from biomass (Hall et al., 1992). Sweden has decided to phase out nuclear plants, reduce fossil-fuel energy usage, and increase the use of biomass energy (Björheden, 2006).

In April 2005, the US Department of Energy (USDOE) and the US Department of Agriculture (USDA) published a joint report commonly referred to as "The Billion Ton Report (BTR)." The purpose of the report was to identify the technical feasibility of producing a billion tons of biomass annually for use as feedstocks for biofuels and bioenergy, which would potentially displace $30 \%$ of our annual petroleum use. This report looked at the production of biomass from two primary landuses, forestland and agricultural land, which are estimated to produce 368 and 998 million dry tons per year respectively by the mid-21st century (USDOE/USDA 2005).

Presently, around the globe, there is a significant interest in using biomass for power generation as power generation from coal continues to raise environmental concerns. Using just biomass for power generation can bring a lot of environmental benefits. The limitations of using biomass alone can include high investments costs and also the security of the feedstock supply which can be attributed to seasonal supply and in most of the countries biomass is dispersed and the infrastructure for biomass supply is not well established (EUROPE, Europe Commission). The technical limitations of using just biomass can be low heating values, low bulk densities which make large units of biomass to be transported (IEA Clean Coal Center, 2005). To overcome these limitations combining biomass and coal for power generation can be a potentially viable alternative. Advantages of co-firing biomass along with coal includes a) Coal can reduce the issues related to biomass quality and buffer the system when there is insufficient feedstock quantity and b) costs of adapting the existing coal power plants will be lower than building new systems dedicated only to biomass (IEA Clean Coal Center, 2005). Type of biomass feedstock available for energy purposes include agricultural residues, dedicated energy crops, forestry, industry, parks and gardens, waste and other. Table 1 shows the list of biomass feedstock material available for power generation. 
Table 1. Types of biomass feedstocks used for energy purposes

\begin{tabular}{|c|c|c|}
\hline $\begin{array}{l}\text { Supply } \\
\text { Sector }\end{array}$ & Type & Example \\
\hline \multirow[t]{2}{*}{$\begin{array}{l}\text { Agricultural } \\
\text { residues }\end{array}$} & $\begin{array}{l}\text { Dry lignocellulosic } \\
\text { agricultural residues }\end{array}$ & $\begin{array}{l}\text { Straw (maize, cereal, rice) } \\
\text { Sugar beet leaves } \\
\text { Residue flows from bulb sector }\end{array}$ \\
\hline & Livestock waste & $\begin{array}{l}\text { Solid manure (chicken manure) } \\
\text { Liquid manure (cattle, pigs, sheep manure) }\end{array}$ \\
\hline \multirow[t]{5}{*}{$\begin{array}{l}\text { Dedicated } \\
\text { energy crops }\end{array}$} & $\begin{array}{l}\text { Dry lignocellulosic } \\
\text { woody energy crops }\end{array}$ & SRW - willow; SRC - poplar; Eucalyptus \\
\hline & $\begin{array}{l}\text { Dry lignocellulosic } \\
\text { herbaceous energy } \\
\text { crops }\end{array}$ & $\begin{array}{l}\text { Miscanthus; Switch grass; Common reed; Reed } \\
\text { canary grass; Giant reed; Cynara cardu; Indian } \\
\text { shrub }\end{array}$ \\
\hline & Oil energy crops & $\begin{array}{l}\text { Sugar beet; Cane beet; Sweet sorghum; Jerusalem } \\
\text { Artichoke; Sugar millet }\end{array}$ \\
\hline & Starch energy crops & $\begin{array}{l}\text { Wheat; Potatoes; Maize; Barley; Triticae; Corn } \\
\text { (cob); Amaranth }\end{array}$ \\
\hline & Others & $\begin{array}{l}\text { Flax (Linum); Hemp (Cannabis); Tobacco stems; } \\
\text { Aquatic plants (lipids from algae); Cotton stalks; } \\
\text { Kenaf }\end{array}$ \\
\hline Forestry & Forestry by-products & $\begin{array}{l}\text { Bark; Wood blocks; Wood chips from tops and } \\
\text { branches; Wood chips from thinning; Logs from } \\
\text { thinning }\end{array}$ \\
\hline \multirow[t]{4}{*}{ Industry } & $\begin{array}{l}\text { Wood industry } \\
\text { Residues }\end{array}$ & $\begin{array}{l}\text { Industrial waste wood from sawmills and } \\
\text { Industrial waste wood from timber mills (bark, } \\
\text { sawdust, wood chips, slabs, off-cuts) }\end{array}$ \\
\hline & & $\begin{array}{l}\text { Fibrous vegetable waste from virgin pulp production } \\
\text { and from production of paper from pulp, including } \\
\text { black liquor }\end{array}$ \\
\hline & $\begin{array}{l}\text { Food industry } \\
\text { Residues }\end{array}$ & $\begin{array}{l}\text { Wet cellulosic material (beet root tails); Fats (used } \\
\text { cooking oils); Tallow, yellow grease; Proteins } \\
\text { (slaughter house waste) }\end{array}$ \\
\hline & Industrial products & $\begin{array}{l}\text { Pellets from sawdust and shavings; Briquettes from } \\
\text { sawdust and shavings; Bio-oil (pyrolisis oil); Ethanol; } \\
\text { Bio-diesel }\end{array}$ \\
\hline \multirow{2}{*}{$\begin{array}{l}\text { Parks and } \\
\text { Gardens }\end{array}$} & Herbaceous & Grass \\
\hline & Woody & Pruning \\
\hline Waste & Contaminated waste & $\begin{array}{l}\text { Demolition wood; Biodegradable; municipal waste; } \\
\text { Sewage sludge; Landfill gas; Sewage gas }\end{array}$ \\
\hline \multirow[t]{2}{*}{ Others } & Roadside hay & Grass/hay \\
\hline & Husks/Shells & Almond; Olive; Walnut; Palm pit ; Cacao \\
\hline
\end{tabular}




\section{Status on biomass co-firing}

Biomass co-firing has been successfully demonstrated in over 150 installations worldwide for most combinations of fuels and boiler types. About a hundred of these have been in Europe. In the United States there have been over 40 commercial demonstrations and the remainder has been mainly in Australia. A broad combination of fuels, such as residues, energy crops, herbaceous and woody biomasses have been co-fired in PCC, stoker and cyclone boilers. The proportion of biomass has ranged from $1 \%$ to $20 \%$. The experience of biomass co-firing in PCC boilers has demonstrated that, co-firing woody biomass resulted in a modest decrease in boiler efficiency but no loss of boiler capacity. There was, however, a considerable reduction of SO2, NOx and mercury emissions. Though herbaceous biomass have been co-fired in several plant worldwide, their higher inorganic matter content results in higher chance of slagging and fouling. Co-firing herbaceous fuels tends to be more difficult and costly than other fuels but it is possible to co-fire there fuels if there is a regulatory incentive to do so.

Biomass co-firing has been used in Europe and the Netherlands in particular for over a decade. Full-scale commercial co-firing of at least 10 percent biomass (based on heat input) is a daily practice, with a wide variety of bio-fuels and co-firing configurations. The technology of co-firing has been demonstrated in many boilers types in Europe.

The US has been slow to adopt biomass co-firing due to its limited full-scale commercial use due to a lack of incentives, and a general reluctance in introducing new fuels into boilers. However, power generation and co-generation from biomass, waste, and recovered fuels is now quickly becoming a hot topic for the power sector as a result of new environmental policies and regulations.

Hughes and Tillman (1998) have reviewed some of the co-firing studies carried out in USA. These authors in their article on "biomass co-firing: status and prospects" have identified the various utilities companies like Tacoma Public Utilities, Northern States Power, and Southern Company has used the biomass for co-firing purposes and anticipated the public benefits.

The commercial operation of the Southern Company was at Georgia Power's Plant Yates. The Yates plant co-firing involved mixing low percentages of wood waste with coal on the coal pile. Since Yates is a PC-based station, the wood waste fine sawdust, and coal are transported together through the coal handling system and the pulverizers enroute to the boilers.

Tacoma Steam Plant \# 2 was repowered by adding two fluidized-bed boilers fired with locally available wood waste, RDF, and coal. The wood fuel used is the locally available hog fuel.

Northern States Power initiated co-firing at its King Station in the year 1987. They have used a $550 \mathrm{MWe}$ cyclone boiler fired with sub-bituminous coal along with finely divided wood waste.

KEMA over the past 15 years has done co-firing with both direct and indirect systems using different biomass. They have tried to co-firing coal and biomass mixtures up to $25 \%$ and have been involved with more than 50 small and full scale biomass trials. In North America, they have performed extensive feasibility studies on co-firing for six large utilities (www. kema.com).

KEMA has recently supervised a fuel supply study, and provided a detailed techno-economic assessment and conceptual design for American Electric Power (AEP), a U.S. public utility holding company. The plant featured an 800 electrical megawatt (MWe) opposed wall pulverized coal-fired boiler; the base load unit. The plant was firing low sulfur Eastern bituminous coal, but after a flue gas desulfurization unit was installed in 2008, it was switched to high sulfur coal, with four to seven pounds sulfur dioxide per one million BTU. The plant had a selective catalytic reduction unit and cold-side electrostatic precipitator installed. 
These commercial experiences have helped to identify the opportunities, and technical barriers, associated with co-firing coal and biomass. Opportunities includes in the area of customer have been demonstrated. Barriers identified includes fuel procurement issues, fuel quality issues, ash quality issues related to flyash sales, and limits to the percentage of biofuels that can be fired under given configurations.

There are various technical issues on co-firing biomass with coal. The major ones being fuel feed, boiler chemistry, and ash deposition and disposal. Some of the issues has been addressed by pretreating the biomass and are reaching to a solution. Losses in boiler efficiency are mostly due to high moisture content in the biomass fuels. A consensus is emerging that cofiring is feasible at most coal-fired power plants. Many power companies sell fly ash as a Portland cement ingredient. An American Society for Testing and Materials standard (C618) requires that only "coal ash" be used in the mixture. Work by DOE and several utilities targets a change in the standard that would allow the use of co-firing ash in portland cement. Success of this effort may encourage many utilities to use biomass because they will still be able to sell their ash.

Co-firing may also be an opportunity for power companies to provide new, environmentally responsible services. This opportunity provides industries, such as construction and transportation, with a way to manage large quantities of wood waste. Co-firing can also provide industries such as forestry, wood products, pulp and paper, agriculture, and food processing with a way to divert large quantities of combustible biomass residues. The cost of biomass fuels can be low when large amounts of wood and agricultural waste are available. Thus, co-firing can simultaneously provide a service to industrial customers and renewable energy for environmentally conscious electricity consumers.

\section{Objective}

There has been research carried on understanding the effect of biomass fuel properties like physical, chemical and biochemical composition and flow properties, in terms of co-firing efficiency (Mohammad et al., 2006 and Hughes and Tillman, 1998). These studies include a) understanding the influence of co-firing on ash properties and flyash sales, b) the influence of co-firing on boiler slagging and fouling problems, c) the influence of fuel blending on pulverizer performance and d) the maximum percentage of co-firing as a function of materials handling and combustion technologies. Not much literature is available in detailing biomass pretreatment methods and their effect on the fuel properties for co-firing purposes. The present research is on understanding biomass classification and composition, fuel properties in relation of co-firing issues and to investigate the available pretreatment methods to overcome these issues.

\section{Coal and Biomass classification and Composition}

\section{Coal}

Coal is formed from ancient plant material accumulated in subsurface environments which prevents the complete decay of the organic matter. Plants that died in a swampy area if covered quickly by water, silt, sand, and other sediments further decompose to carbon dioxide and water under normal circumstances. Instead under anaerobic conditions with the help of anaerobic bacteria, (bacteria that do not require oxygen to live) the plant debris reduces to simpler forms: primarily pure carbon and simple compounds of carbon and hydrogen (hydrocarbons) the process by which coal is formed. The initial stage of decay of dead plants is a soft, woody material known as peat. In some parts of the world, peat is still collected from boggy areas and used as a fuel. Peat is not considered as good a fuel, as it burns poorly and releases a lot of 
smoke. If peat is allowed to remain in the ground for long periods of time, it eventually becomes compacted as layers of sediment known as overburden, collect above it. The additional pressure and heat of the overburden gradually converts peat into another form of coal known as lignite or brown coal. Continued compaction by overburden then converts lignite into bituminous (or soft) coal and finally, anthracite (or hard) coal..

Although fossil fuels have their origin in ancient biomass, they are not considered biomass by the generally accepted definition because they contain carbon that has been "out" of the carbon cycle for a very long time. Their combustion therefore disturbs the carbon dioxide content in the atmosphere. Technically coal is a sedimentary rock with a chemical structure similar to that of a polymer. Its structure varies based on the age of the coal and therefore the amount of pressure applied to it over time. The typical coal structure consists of numerous aromatic rings of five or six carbons bonded with principally hydrogen, nitrogen, sulfur, and oxygen atoms. Nitrogen, hydrogen, and sulfur are responsible for the majority of coal's chemical properties. The nitrogen and oxygen atoms in coal result in a readily combustible structure which has made coal a popular fuel and source of heat throughout history. The main types of coal are listed below from youngest:

$>$ Peat (technically a precursor to coal)

$>$ Lignite

$>$ Sub-bituminous coal

$>$ Bituminous coal

$>$ Anthracite (pictured below)

$>$ Graphite

Coal was first mined as fuel as far back as 10,000 years ago in China. During the last three hundred years, coal has played an important role in the technological advances, culture, and the global economy. Presently, coal is at the center of controversy as coal mining is high risk and has many social concerns including the production of greenhouse gases when combusted. Even with all the social and environmental concerns, coal continues to be an important and improved source of fuel in the twenty first century.

The United States has more coal than the rest of the world has oil. There is still enough coal underground in US to provide energy for the next 200 to 300 years. Trapped inside coal are traces of impurities like sulfur and nitrogen. When coal burns, these impurities are released into the air which further combine with water vapor to form weak forms of sulfuric and nitric acid also known as "acid rain."

Coals are classified upon the ratios which the volatile materials or hydro-carbons bear to fixed carbon. Anthracite coal is low in volatile material and high in fixed carbon. Soft coals are high in volatile matter and low in carbon. Volatile hydrocarbons in different coal are given in Table 2.

Table 2 The percentage of coal in volatile hydrocarbons runs are as follows

\begin{tabular}{ll}
\hline Anthracite & 3.6 \\
Semi-Anthracite & 6.12 \\
Semi-bituminous & 2.18 \\
Bituminous & 8.50
\end{tabular}

The remaining components of the coals are absorbed moisture, fixed carbon and ash. The ash in a first class coal should not be above 8 per cent.

Coal is also classified according to its heating value and relative content of elemental carbon. Anthracite contains the highest proportion of pure carbon (about 86\%-98\%) and has the highest heat value-13,500-15,600 Btu/lb of all forms of coal. Bituminous coal generally has lower 
concentrations of pure carbon (from $46 \%$ to $86 \%$ ) and lower heat values (8,300-15,600 Btu/lb). Bituminous coals are often sub-divided on the basis of their heat value, being classified as low, medium, and high volatile bituminous and sub-bituminous. Lignite, the poorest of the true coals in terms of heat value (5,500-8,300 Btu/lb) generally contains about $46 \%-60 \%$ pure carbon. All forms of coal also contain other elements present in living organisms, such as sulfur and nitrogen, which are very low in absolute numbers, but have important environmental consequences when coal is used as fuel. Typical coal analysis for Central Appalachian, Illinois Basin, Powder River Basin and N. Dakota Lignite are given in Table 3.

Table 3. Typical coal composition

\begin{tabular}{|c|c|c|c|c|}
\hline Parameter & $\begin{array}{l}\text { Central } \\
\text { Appalachian } \\
\text { (Long Fork) }\end{array}$ & $\begin{array}{l}\text { Illinois } \\
\text { Basin }\end{array}$ & $\begin{array}{l}\text { Powder River } \\
\text { Basin (Black } \\
\text { Thunder) }\end{array}$ & $\begin{array}{l}\text { N. Dakota } \\
\text { Lignite }\end{array}$ \\
\hline \multicolumn{5}{|l|}{ Proximate Analysis (wt. \%) } \\
\hline Moisture & 7.16 & 5.98 & 25.84 & 26.74 \\
\hline Ash & 11.52 & 10.63 & 5.05 & 12.52 \\
\hline Volatile matter & 31.23 & 35.11 & 31.56 & 31.58 \\
\hline Fixed Carbon & 50.09 & 48.28 & 37.55 & 29.16 \\
\hline \multicolumn{5}{|l|}{ Ultimate Analysis (wt. \% ) } \\
\hline Carbon & 66.93 & 60.68 & 51.89 & 31.80 \\
\hline Hydrogen & 4.43 & 4.77 & 3.55 & 4.51 \\
\hline Oxygen & 7.55 & 13.61 & 12.77 & 26.35 \\
\hline Nitrogen & 1.34 & 1.09 & 0.67 & 0.59 \\
\hline Sulfur & 1.07 & 3.24 & 0.23 & 0.84 \\
\hline Moisture & 7.16 & 5.98 & 25.84 & 26.74 \\
\hline Ash & 11.52 & 10.63 & 5.05 & 9.17 \\
\hline Chlorine (\%) & 0.12 & 0.30 & 0.01 & \\
\hline Higher Heating Value (Btu/lb) & 12114 & 10334 & 8943 & 7613 \\
\hline \multicolumn{5}{|l|}{ Ash Elemental Analysis (\% Dry) } \\
\hline $\mathrm{Al} 2 \mathrm{O} 3$ & 26.25 & 16.49 & 16.20 & 14.01 \\
\hline $\mathrm{BaO}$ & 0.13 & & 0.67 & \\
\hline $\mathrm{CaO}$ & 2.31 & 6.71 & 22.84 & 13.69 \\
\hline $\mathrm{Fe} 2 \mathrm{O} 3$ & 8.38 & 20.41 & 6.02 & 7.39 \\
\hline $\mathrm{K} 2 \mathrm{O}$ & 3.26 & 1.66 & 0.56 & 0.51 \\
\hline $\mathrm{MgO}$ & 1.42 & 0.77 & 5.22 & 2.51 \\
\hline $\mathrm{MnO}$ & 0.07 & 0.06 & 0.01 & 0.12 \\
\hline $\mathrm{Na} 2 \mathrm{O}$ & 0.71 & 1.09 & 1.44 & 0.60 \\
\hline P2O5 & 0.56 & 0.45 & 1.57 & 0.39 \\
\hline $\mathrm{SiO} 2$ & 51.99 & 39.19 & 32.76 & 38.17 \\
\hline $\mathrm{SrO}$ & 0.19 & & 0.36 & \\
\hline $\mathrm{TiO} 2$ & 1.07 & 0.84 & 1.28 & 1.15 \\
\hline SO3 & 2.20 & 5.43 & 10.10 & 14.41 \\
\hline
\end{tabular}

Source: Tillman et al. (2009)

\section{Biomass}

Biomass, a renewable energy source, is biological material derived from living, or recently living organisms, such as wood and herbaceous material. Historically, biomass is used to generate electricity or produce heat through direct incineration. Forest residues for example (such as dead trees, branches and tree stumps), yard clippings, wood chips and municipal solid waste are often used for this purpose. However, biomass also includes plant or animal matter used for 
production of fibers or chemicals. Biomass may also include biodegradable wastes that can be burnt as fuel. It excludes organic materials such as fossil fuels which have been transformed by geological processes into substances such as coal or petroleum. Industrial biomass can be grown from numerous types of plants, including miscanthus, switchgrass, hemp, corn, poplar, willow, sorghum, sugarcane (Volk et al., 2000) and a variety of tree species, ranging from eucalyptus to oil palm (palm oil).

Biomass covers a whole gamut of energy forms. By definition biomass is "The total mass of living organisms in a given area or of a given species usually expressed as dry weight. Biomass also includes organic matter products, by-products and waste derived from living organisms (especially regarded as fuel) excluding peat from such material. Cellulosic biomass is biomass from cellulose, the primary structural component of plants and trees." - IPCC 2007. Other terms which also have biomass as their basis are biofuel, vegioil, bioenergy, bioethanol, biogas \& etc. The great advantage of biofuels is that they are considered to be 'carbon neutral' as they use up as much carbon dioxide during growth, as they expel as a fuel.

Biomass, once processed, is also referred to "feedstock." Different feedstocks available for energy purposes include: oil seeds, grains, sugar crops, agricultural residues, trees, grasses, and algae (Pena 2008). Agricultural residues, trees, and grasses, are referred to as cellulosic biomass. Different parts of the plants are used depending on the category of feedstock. To give an example biodiesel can be produced directly from the fats and oils from oils seeds like soybeans etc. (Pena 2008). The product derived from a particular feedstock is dependent on which part of the plant and the conversion process used. The possible products that can be derived from biomass include biodiesel, ethanol, butanol, methane, hydrocarbons, and natural oils, which can be further processed into any number of desirable fuels (Pena, 2008).

The European committee for standardization (CEN) published 27 technical specifications (prestandards) for solid biofuels during 2003-2006. Classification of biomass helps to differentiate the raw material based on their origin with all the details. These are upgraded to common standards to all the countries in Europe and are labeled as EN standards. The two most important technical specifications developed are for classification and specification (EN 14961) and quality assurance for solid biofuels (EN 15234). The classification of solid biofuels is based on the origin and source. This will help to trace the fuel production chain. The solid fuels are divided by the following sub-categories.
a) Woody biomass
b) Herbaceous biomass
c) Fruit biomass
d) Blends and mixtures

According to EN standards, woody biomass includes trees, bushes, and shrubs while herbaceous biomass includes plants that have non-woody stem and which die back at the end of the growing season. Fig. 2 indicates the woody biomass classification based on plantation, by products and used wood. Herbaceous biomass also includes grains and their by products such as cereals. Fruit biomass from parts of a plant which hold the seeds and blends refer to intentional mixing of biomass and mixtures refer to the unintentional mixed biomass. Tables 4,5 and 6 indicate the detail classification of woody, herbaceous, fruit and blends and mixtures. Table 7 indicates typical biomass composition of wood and agricultural residues. It is very clear from the table that ash content and volatile content are higher in agricultural biomass compared to wood, making wood a more suitable candidate for co-firing purposes. 


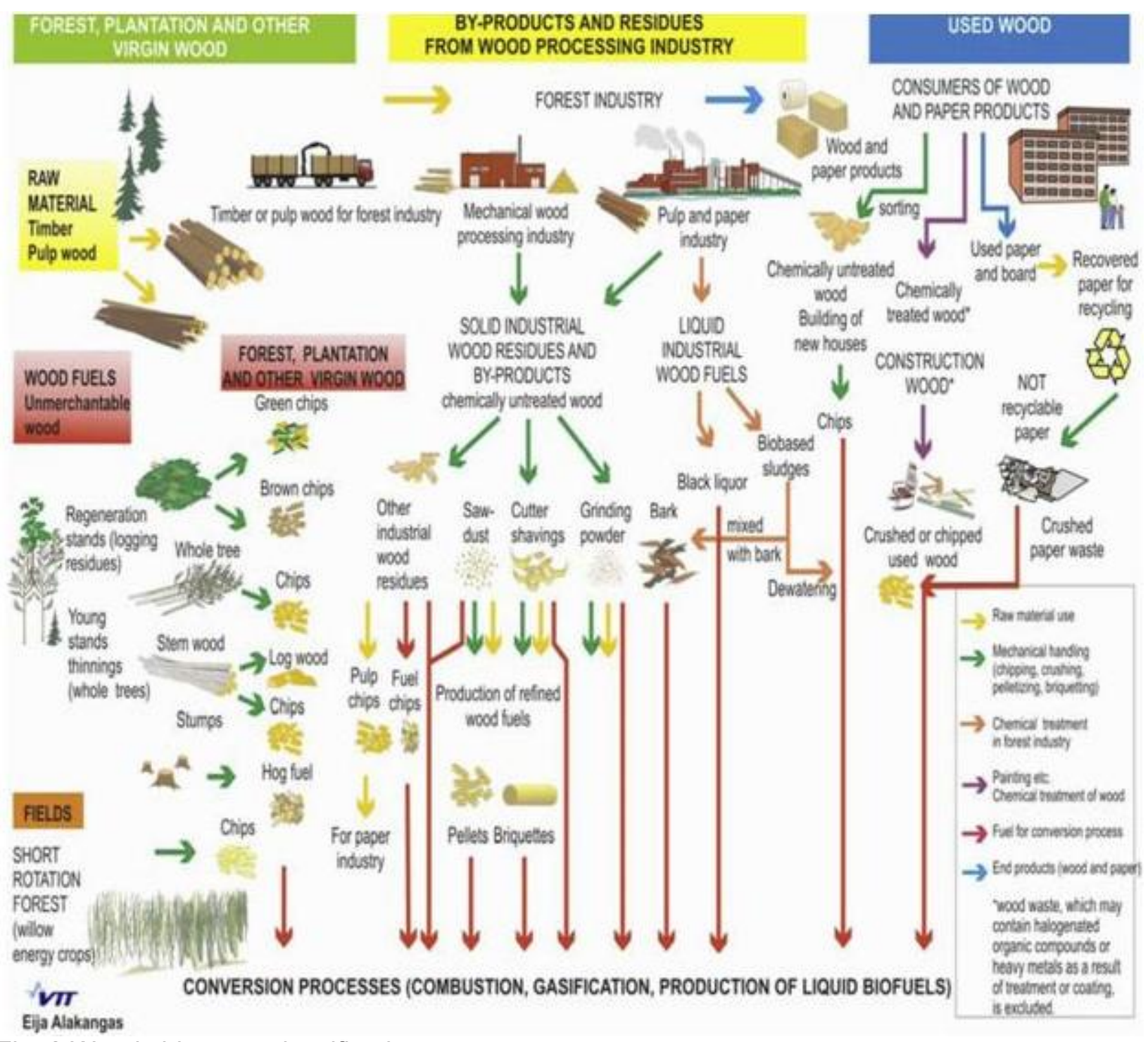

Fig. 2 Woody biomass classification

(Source: Eubionet III-Alakangas, E Classification of biomass origin in European solid biofuels standards) 
Table 4. Classification of 1 woody biomass (EN 14961-1)

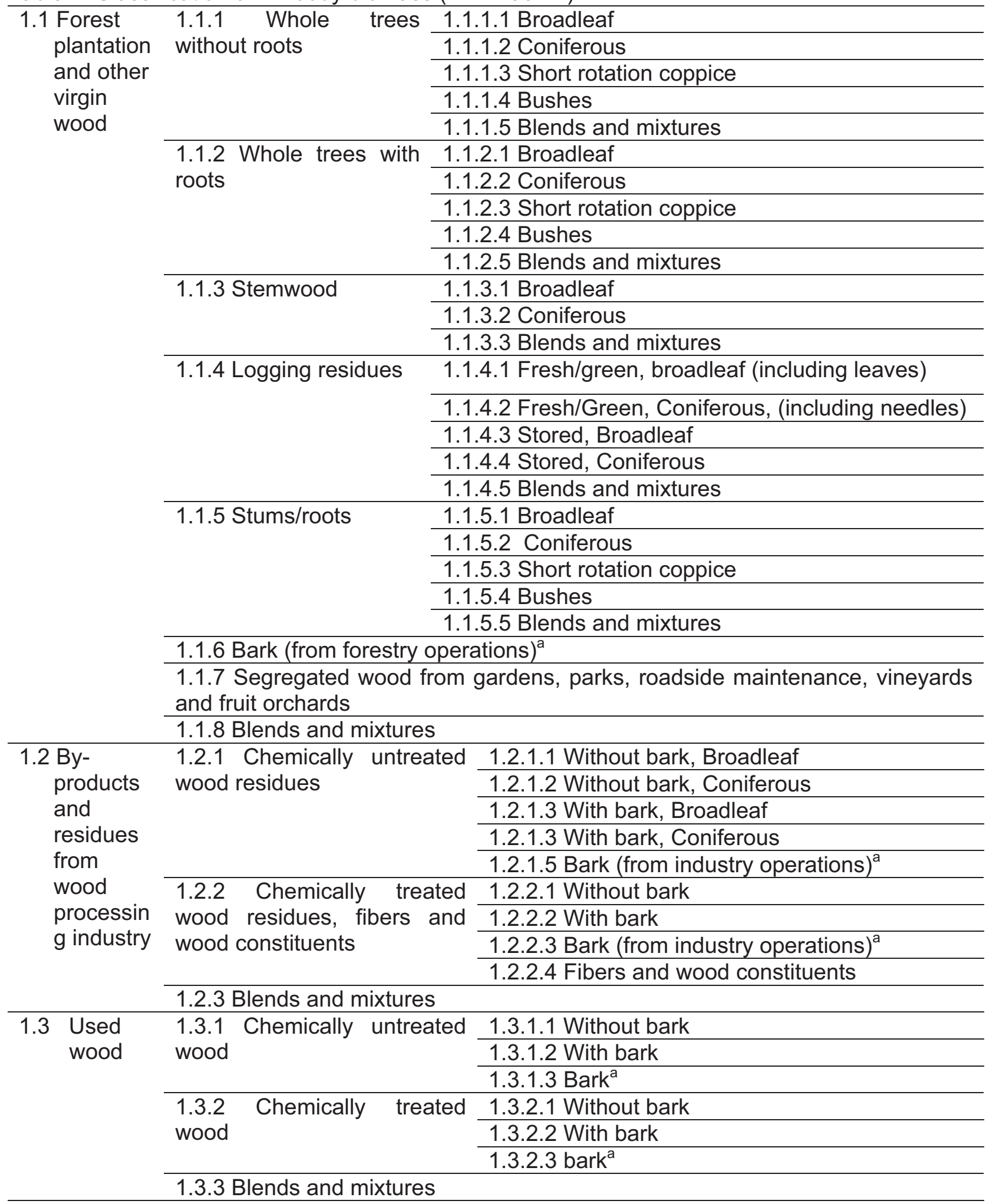

1.4 Blends and mixtures.

${ }^{a}$ Cord is not included in bark 
Table 5. Classification of 2 herbaceous biomass (EN 14961-1)

\begin{tabular}{|c|c|c|}
\hline \multirow{29}{*}{$\begin{array}{l}\text { 1.1 Herbaceous } \\
\text { biomass }\end{array}$} & \multirow[t]{4}{*}{ 2.1.1 Cereal crops } & 2.1.1.1 Whole plant \\
\hline & & 2.1.1.3 Grain or seeds \\
\hline & & 2.1.1.4 Husk or shells \\
\hline & & 2.1.1.5 Blends and mixtures \\
\hline & \multirow[t]{5}{*}{ 2.1.2 Grasses } & 2.1.2.1 Whole plant \\
\hline & & 2.1.2.2 Straw parts \\
\hline & & 2.1.2.3 Seeds \\
\hline & & 2.1.2.4 Shells \\
\hline & & 2.1.2.5 Blends and mixtures \\
\hline & \multirow[t]{5}{*}{ 2.1.3 Oil seed crops } & 2.1.3.1 Whole plant \\
\hline & & 2.1.3.2 Stalk and leaves \\
\hline & & 2.1.3.3 Seeds \\
\hline & & 2.1.3.4 Husks or shells \\
\hline & & 2.1.3.5 Blends and mixtures \\
\hline & \multirow[t]{4}{*}{ 2.1.4 Root crops } & 2.1.4.1 Whole plant \\
\hline & & 2.1.4.2 Stalk and leaves \\
\hline & & 2.1.4.3 Root \\
\hline & & 2.1.4.4 Blends and mixtures \\
\hline & \multirow[t]{5}{*}{ 2.1.5 Legume crops } & 2.1.5.1 Whole plant \\
\hline & & 2.1.5.2 Stalk and leaves \\
\hline & & 2.1.5.3 Fruit \\
\hline & & 2.1.5.4 Pods \\
\hline & & 2.1.5.5 Blends and mixtures \\
\hline & \multirow[t]{4}{*}{ 2.1.6 Flowers } & 2.1.6.1 Whole plant \\
\hline & & 2.1.6.2 Stalk and leaves \\
\hline & & 2.1.6.3 Seeds \\
\hline & & 2.1.6.4 Blends and mixtures \\
\hline & \multicolumn{2}{|l|}{$\begin{array}{l}\text { 2.1.7 Segregated herbaceous } \\
\text { maintenance, vineyards, and fr }\end{array}$} \\
\hline & \multicolumn{2}{|l|}{ 2.1.8 Blends and mixtures } \\
\hline \multirow{13}{*}{$\begin{array}{l}2.2 \text { By-products } \\
\text { and residues } \\
\text { from } \\
\text { herbaceous } \\
\text { processing } \\
\text { industry }\end{array}$} & \multirow{6}{*}{$\begin{array}{l}2.2 .1 \text { Chemically untreated } \\
\text { herbaceous residues }\end{array}$} & 2.2.1.1 Cereal crops and grasses \\
\hline & & 2.2.1.2 Oil seed crops \\
\hline & & 2.2.1.3 Root crops \\
\hline & & 2.2.1.4 legume crops \\
\hline & & 2.2.1.5 flowers \\
\hline & & 2.2.1.6 Blends and mixtures \\
\hline & \multirow{6}{*}{$\begin{array}{l}2.2 .2 \text { Chemically treated } \\
\text { herbaceous residues }\end{array}$} & 2.2.2.1 Cereal crops and grasses \\
\hline & & 2.2.2.2 Oil seed crops \\
\hline & & 2.2.2.3 Root crops \\
\hline & & 2.2.2.4 legume crops \\
\hline & & 2.2.2.5 flowers \\
\hline & & 2.2.2. 6 Blends and mixtures \\
\hline & \multicolumn{2}{|l|}{ Blends and mixtures } \\
\hline
\end{tabular}




\begin{tabular}{llll}
\hline $\mathrm{CaO}$ & 45.46 & 5.60 & 8.80 \\
$\mathrm{Fe}_{2} \mathrm{O}_{3}$ & 1.58 & 2.03 & 1.80 \\
$\mathrm{~K}_{2} \mathrm{O}$ & 8.52 & 11.60 & 17.30 \\
$\mathrm{MgO}$ & 7.48 & 3.00 & 3.40 \\
$\mathrm{MnO}$ & & & \\
$\mathrm{Na}_{2} \mathrm{O}$ & 2.13 & 0.58 & 1.50 \\
$\mathrm{P}_{2} \mathrm{O}_{5}$ & 7.44 & 4.50 & 2.70 \\
$\mathrm{SiO}_{2}$ & 17.78 & 65.18 & 52.10 \\
$\mathrm{SrO}_{\mathrm{TiO}}$ & & & \\
$\mathrm{SO}_{3}$ & 0.50 & 0.24 & 0.13 \\
\hline
\end{tabular}

Source: Tillman et al. (2009)

\section{Biofuels}

Biofuel is defined as: "Any liquid, gaseous, or solid fuel produced from plant or animal organic matter. Second-generation biofuels are products such as ethanol and biodiesel derived from ligno-cellulosic biomass by chemical or biological processes." -IPCC 2007

Biofuels are derived from various plant parts and the conversion process used to convert the plant part determines the biofuel that can be produced. Each biofuel displaces different quantities of fossil fuel equivalents. The conversion of biomass to biofuel can also result in byproducts, which are usually plant parts and materials that cannot be converted due chemical composition.

The final step in the production of bioenergy, defined as "energy derived from biomass (IPCC 2007)", is the consumption of biofuels to produce electricity, heat, or steam. Heat is the form of energy used in combustion engines, which we typically associate with biofuel consumption. Unprocessed biomass can also be directly burned to produce heat, as is the case when wood is burned in a fireplace. The previously mentioned by-products can also be directly burned to produce bioenergy in the form of heat.

\section{Biomass co-firing}

Co-firing is the burning of more than one type of fuel simultaneously. Usually, the term is used to describe the burning of coal with another fuel source. The fuel can be mixed with the coal outside the combustor, or the fuels can be added to the combustor separately. The most common type of facility for co-firing is large, coal-fired power plants, however, other coal-burning facilities, like cement kilns, industrial boilers, and coal-fired heating plants, are also good candidates for co-firing.

Co-firing biomass can be a low-cost option for converting biomass to electricity efficiently and cleanly by adding biomass as a partial substitute fuel in high-efficiency coal boilers. In all the boiler types commonly used by electric utilities, it has been proven that there will be little or no loss in total boiler efficiency after adjusting combustion output for the new fuel mixture. This implies that biomass combustion efficiency to electricity would be close to $33 \%-37 \%$ when cofired with coal. Extensive studies on biomass co-firing has indicated that biomass can provide about $15 \%$ of the total energy input with modification of feed intake and burner modifications.

Co-firing biomass with coal offers several environmental benefits like reduced emissions of carbon dioxide. With less sulfur in the biomass than in most coals a significant reduction of emissions of sulfurous gases like sulfur dioxide also occurs. A couple of studies on co-firing 
woody biomass with coal showed significant reduction, about $30 \%$, in oxides of nitrogen which results in smog and ozone pollution.

In general, there are four alternative approaches to injecting biomass into the generation process. Each approach targets different parts of the process, as shown in Figure 1.

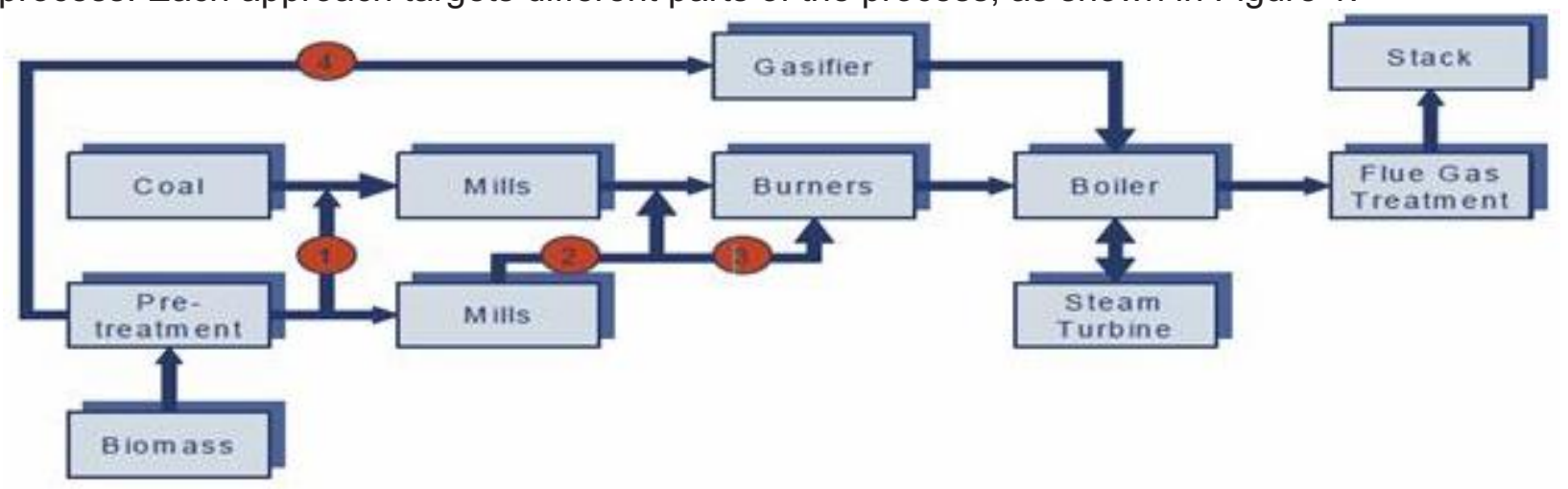

Figure 1. Alternative Co-firing Approaches (Source: www.kema.com)

Approach 1 blends the coal/biomass mixture on a conveyor belt and co-mills the fuel mixture in the existing coal pulverizers, then combusts in the existing coal burners. Approach 2 separates biomass pre-processing (milling and drying), followed by injection of the biomass in the pulverized fuel lines (after the pulverizers) and simultaneous biomass/coal combustion in the original or modified coal burners. Approach 3 separates biomass pre-processing, feeding and combustion in separate, dedicated biomass burners. Finally, approach 4 provides for indirect co-firing of biomass; for example, through an upfront gasifier with co-combustion of the (cleaned) fuel gas in the main coal-fired boiler.

\section{Technical considerations for co-firing}

Each of these approaches has its own unique operational requirements, limitations and constraints, and puts specific demands on both the fuel quality and the achievable biomass percentage. Constrains which include technical, regulatory and economic considerations associated with the all the above approaches are given below (www.kema.com).

$>$ Permitting requirements, specific site restrictions

$>$ Fuel type, availability and quality

$>$ Storage capacity, required road/rail movements, fuel logistics

$>$ Required fuel handling, pre-processing (drying, milling)

$>$ Pulverizer capacity and performance

$>$ Burner arrangement, available space in the boiler house

$>$ Possibilities for injecting biomass into the boiler

$>$ Boiler performance, steam conditions, net power output, re-powering options

$>$ Existing boiler limitations

$>$ Corrosion, slagging, fouling propensity

$>$ Flue gas cleaning operation and performance

$>$ Emissions constraints

$>$ Ash quality requirements

$>$ Health and safety aspects 


\section{Regulatory, Environmental and Economic considerations}

Regulatory and environmental considerations include current and expected upcoming renewable energy policies, carbon dioxide emission-reduction targets, tax incentives, and new legislation with respect to waste disposal (www.kema.com). Economic considerations include the cost of biomass from identified fuel supplier(s), coal costs, required capital for co-firing installation, ongoing operations and maintenance costs, and the corporate finance model (weighted average cost of capital, tax rate, inflation, etc.).

Environmental taxes and credits, and the cost of meeting renewable portfolio standards are also considered. The assessment can also consider: benefits from reduced sulfur dioxide, nitrogen oxide, and/or mercury emissions; reduced ash landfill costs or income from ash applications; renewable energy certificates (RECs); and production tax credits (PTCs). The cost of emitting carbon should be assessed against the cost of breaking even with biomass (www.kema.com).

\section{Coal versus biomass combustion}

One of the reasons biomass is a good candidate for co-firing with coal is that both biomass and coal are solid fuels and the equipment designed to burn coal is assumed to be able to use biomass as well. However, coal and biomass have differences in their chemical composition. Table 8 indicates typical properties of different solid fuels which include both coal and biomass. Most notably, biomass has a higher fraction of hydrogen and oxygen, and less carbon than coal. As a result, biomass tends to generate less energy than coal, about two-thirds as much, on a mass basis. In addition, the differences in composition cause biomass to have a higher fraction of volatile matter, which causes it to have more "flaming combustion" and less "char combustion" (glowing coals). This difference can affect the optimum sizing and design of the combustion chamber, as well as the ideal flow rate and location of combustion air.

Table 8 Typical elemental composition of Pennsylvania coal and biomass

\begin{tabular}{|l|c|c|c|c|c|c|c|c|c|}
\hline Fuel Percent & $\mathrm{C}$ & $\mathrm{H}$ & $\mathrm{O}$ & $\mathrm{N}$ & $\mathrm{S}$ & $\mathrm{Si}$ & $\mathrm{K}$ & $\mathrm{Ca}$ & $\mathrm{Cl}$ \\
\hline Anthracite coal & $91-94$ & $2-4$ & $2-5$ & $\begin{array}{c}0.6- \\
1.2\end{array}$ & $\begin{array}{c}0.6- \\
1.2\end{array}$ & $2-6$ & $\begin{array}{c}0.1- \\
0.5\end{array}$ & $\begin{array}{c}0.03- \\
0.2\end{array}$ & $\begin{array}{c}0.01- \\
0.2\end{array}$ \\
\hline Bituminous coal & $83-89$ & $4-6$ & $3-8$ & $\begin{array}{c}1.4- \\
1.6\end{array}$ & $\begin{array}{c}1.4- \\
1.7\end{array}$ & $2-3$ & $\begin{array}{c}0.1- \\
0.2\end{array}$ & $\begin{array}{c}0.1- \\
0.3\end{array}$ & $\begin{array}{c}0.01- \\
0.13\end{array}$ \\
\hline Wood, clean \& dry & 50 & 6.1 & 43 & 0.2 & - & 0.05 & 0.1 & 0.04 & - \\
\hline Switchgrass & 48 & 5.5 & 43 & 0.2 & - & 1.4 & 0.4 & 0.2 & - \\
\hline
\end{tabular}

Note: $\mathrm{C}=$ Carbon; $\mathrm{H}=$ Hydrogen; $\mathrm{O}=$ Oxygen; $\mathrm{N}=$ Nitrogen; $\mathrm{Si}=$ Silicon; $\mathrm{K}=$ Potassium; $\mathrm{Ca}=$ Calcium; $\mathrm{Cl}=$ Chlorine

Source: Miller and Tillman (2008) and Bain et al. (2003).

\section{Biomass fuel properties and their influence on co-firing}

Biomass in general has a proximate analysis of $80 \%$ volatile matter and $20 \%$ fixed carbon (moisture and ash free basis) where as group-1 bituminous coal has $70-80 \%$ fixed carbon and $20-30 \%$ volatile matter. Table 9 and 10 compares coal and biomass properties showing that different types of biomasses have differences within the group, especially with regards to moisture and ash content. 
Table 9. Typical properties of different solid fuels

\begin{tabular}{|c|c|c|c|c|c|c|c|c|c|}
\hline Property & Coal & Peat & $\begin{array}{l}\text { Wood } \\
\text { without } \\
\text { bark }\end{array}$ & Bark & $\begin{array}{l}\text { Forest } \\
\text { residues } \\
\text { (coniferous } \\
\text { tree with } \\
\text { needles) }\end{array}$ & Willow & Straw & $\begin{array}{l}\text { Reed } \\
\text { canary } \\
\text { grass } \\
\text { (spring } \\
\text { harvest) }\end{array}$ & $\begin{array}{l}\text { Olive } \\
\text { residues }\end{array}$ \\
\hline $\begin{array}{l}\text { Ash } \\
\text { content } \\
\text { (bd) }\end{array}$ & $\begin{array}{l}8.5- \\
10.9\end{array}$ & $4-7$ & $0.4-0.5$ & $2-3$ & $1-3$ & $\begin{array}{l}1.1- \\
4.0\end{array}$ & 5 & $6.2-7.5$ & $2-7$ \\
\hline $\begin{array}{l}\text { Moisture } \\
\text { content } \\
(w \%)\end{array}$ & $6-10$ & $40-55$ & $50-60$ & $45-65$ & $50-60$ & $50-60$ & $17-25$ & $15-20$ & $60-70$ \\
\hline $\begin{array}{l}\mathrm{NCV} \\
(\mathrm{MJ} / \mathrm{kg})\end{array}$ & $\begin{array}{l}26- \\
28.3\end{array}$ & $\begin{array}{l}20.9- \\
21.3\end{array}$ & $\begin{array}{l}18.5- \\
20\end{array}$ & $\begin{array}{l}18.5- \\
23\end{array}$ & $18.5-20$ & $\begin{array}{l}18.4- \\
19.2\end{array}$ & 17.4 & $\begin{array}{l}17.1- \\
17.5\end{array}$ & $17.5-19$ \\
\hline$C, \% \mathrm{db}$ & $76-87$ & $52-56$ & $48-52$ & $48-52$ & $48-52$ & $47-51$ & $45-47$ & $\begin{array}{l}45.5- \\
46.1\end{array}$ & $48-50$ \\
\hline $\mathrm{H}, \% \mathrm{db}$ & $3.5-5$ & $5-6.5$ & $6.2-6.4$ & $\begin{array}{l}5.7- \\
6.8\end{array}$ & $6-6.2$ & $\begin{array}{l}5.8- \\
6.7\end{array}$ & $\begin{array}{l}5.8- \\
6.0\end{array}$ & $5.7-5.8$ & $5.5-6.5$ \\
\hline $\mathrm{N}, \% \mathrm{db}$ & $\begin{array}{l}0.8- \\
1.5\end{array}$ & $1-3$ & $0.1-0.5$ & $\begin{array}{l}0.3- \\
0.8\end{array}$ & $0.3-0.5$ & $\begin{array}{l}0.2- \\
0.8\end{array}$ & $\begin{array}{l}0.4- \\
0.6\end{array}$ & $\begin{array}{l}0.65- \\
1.04\end{array}$ & $0.5-1.5$ \\
\hline $\mathrm{O}, \% \mathrm{db}$ & $\begin{array}{l}2.8- \\
11.3\end{array}$ & $30-40$ & $38-42$ & $\begin{array}{l}24.3- \\
40.2\end{array}$ & $40-44$ & $40-46$ & $40-46$ & 44 & 34 \\
\hline S, \%db & $\begin{array}{l}0.5- \\
3.1\end{array}$ & $\begin{array}{l}<0.05 \\
-0.3\end{array}$ & $<0.05$ & $<0.05$ & $<0.05$ & $\begin{array}{l}0.02- \\
0.10\end{array}$ & $\begin{array}{l}0.05- \\
0.2\end{array}$ & $\begin{array}{l}0.08- \\
0.13\end{array}$ & $\begin{array}{l}0.07- \\
0.17\end{array}$ \\
\hline $\mathrm{Cl}, \% \mathrm{db}$ & $<0.1$ & $\begin{array}{l}0.02- \\
0.06\end{array}$ & $\begin{array}{l}0.01- \\
0.03\end{array}$ & $\begin{array}{l}0.01- \\
0.03\end{array}$ & $0.01-0.04$ & $\begin{array}{l}0.01- \\
0.05\end{array}$ & $\begin{array}{l}0.14- \\
0.97\end{array}$ & 0.09 & $\begin{array}{l}0.1 \text { (in } \\
\text { ash) }\end{array}$ \\
\hline $\mathrm{K}, \% \mathrm{db}$ & 0.003 & $\begin{array}{l}0.8- \\
5.8\end{array}$ & $\begin{array}{l}0.02- \\
0.05\end{array}$ & $\begin{array}{l}0.1- \\
0.4\end{array}$ & $0.1-0.4$ & $\begin{array}{l}0.2- \\
0.5\end{array}$ & $\begin{array}{l}0.69- \\
1.3\end{array}$ & $0.3-0.5$ & $\begin{array}{l}30 \text { (in } \\
\text { ash) }\end{array}$ \\
\hline $\mathrm{Ca}, \% \mathrm{db}$ & $4-12$ & $\begin{array}{l}0.05- \\
0.1\end{array}$ & $0.1-1.5$ & $\begin{array}{l}0.02- \\
0.08\end{array}$ & $0.2-0.9$ & $\begin{array}{l}0.2- \\
0.7\end{array}$ & $\begin{array}{l}0.1- \\
0.6\end{array}$ & 9 & no data \\
\hline
\end{tabular}

$\mathrm{db}$ - dry basis, $\mathrm{MC}$-moisture content $\mathrm{w} \%=$ percent wet basis; \%bd- percent dry basis

Biomass usually has high moisture content resulting in a relatively low fuel calorific value. Fresh wood typically contains $50 \%$ water by weight, whereas bituminous coals are approximately $5 \%$. This high moisture content of the biomass affects its combustion properties. Higher moisture content will reduce the maximum combustion temperature and increase the necessary residence time of feedstock in a combustion chamber, and consequently could result in incomplete combustion and increased emissions (volume of flue gas produced per energy unit) (CEN-335-Solid biofuels, Fuel Specifications and classes, March 2003).

Typically biomass contains less ash than coal and its composition is based on the chemical components required for plant growth, whereas coal ash reflects mineralogical composition. In both coal and biomass, ash-forming matter can be present in four general forms: easily leachable salts, inorganic elements associated with the organic matter of the biomass, minerals included in the fuel structure and inorganic material - typically sand, salt or clay. Alkaline metals that are usually responsible for fouling of heat transfer surfaces are high in biomass ash and are 
released in the gas phase during combustion. These inorganic compounds are in the form of salts or bound in the organic matter. In peat, for example, inorganic matter is bound mostly in silicates, which are more stable at high temperature. The elemental composition of ash (alkali metals, phosphorus, chlorine, silicon and calcium) affects ash-melting behavior. Chlorine, a minor constituent in virtually all coals and all biofuels, contributes to a number of combustion phenomena depending upon concentration. Even a small concentration of chlorine in the fuel can result in deposition of harmful alkaline and chlorine compounds on boiler heat transfer surfaces. Numerous corrosion mechanisms exist with chlorine in solid fuels. These mechanisms have been elucidated for biomass co-firing with coal. With regard to chemical properties of biomass, it generally has less sulfur, fixed carbon, and fuel bound nitrogen, but more oxygen than coal. Another characteristic of biomass is it has low bulk energy density, hydrophilic in nature and non-friable character (CEN-335-Solid biofuels, Fuel Specifications and classes, March 2003). Table 11 indicates the physical and chemical characteristics of biomass and their influence on co-firing.

Table 10. Comparison of selected parameters of different varieties of coal and biomass

\begin{tabular}{|c|c|c|c|c|c|c|}
\hline \multirow[t]{2}{*}{ Parameter } & \multicolumn{4}{|l|}{ Coal } & \multicolumn{2}{|c|}{ Biomass } \\
\hline & $\begin{array}{l}\text { Central } \\
\text { Appalachian }\end{array}$ & $\begin{array}{l}\text { Illinois } \\
\text { Basin }\end{array}$ & $\begin{array}{l}\text { Powder } \\
\text { River } \\
\text { Basin }\end{array}$ & Lignite & $\begin{array}{l}\text { Wood } \\
\text { waste }\end{array}$ & Switchgrass \\
\hline $\mathrm{HHV}, \mathrm{Btu} / \mathrm{lb}$ & 12114 & 10334 & 8943 & 7613 & 5028 & 7002 \\
\hline $\begin{array}{l}\mathrm{Ib} / 10^{6} \text { Btu of } \\
\text { Fuel }\end{array}$ & 83 & 97 & 112 & 131 & 199 & 143 \\
\hline $\mathrm{Fe} 2 \mathrm{O} 3 / \mathrm{CaO}$ & 3.63 & 3.04 & 0.26 & 0.54 & 0.03 & 0.36 \\
\hline $\mathrm{Ib} \mathrm{Cl} / 10^{6} \mathrm{Btu}$ & 0.10 & 0.29 & 0.01 & 0.01 & 0.03 & 0.26 \\
\hline $\begin{array}{l}\mathrm{lb}(\mathrm{Na} 2 \mathrm{O}+ \\
\mathrm{K} 2 \mathrm{O}) / 10^{6} \mathrm{Btu}\end{array}$ & 0.38 & 0.28 & 0.11 & 0.13 & 0.49 & 1.41 \\
\hline $\mathrm{lb} \mathrm{S} / 10^{6} \mathrm{Btu}$ & 0.88 & 3.14 & 0.26 & 1.10 & 0.14 & 0.24 \\
\hline $\begin{array}{l}\mathrm{lb} \mathrm{H} 2 \mathrm{O} / 10^{6} \\
\mathrm{Btu}\end{array}$ & 5.91 & 5.79 & 28.89 & 35.12 & 83.53 & 14.05 \\
\hline $\mathrm{Ib}$ ash $/ 10^{6} \mathrm{Btu}$ & 9.51 & 10.29 & 5.65 & 12.05 & 4.59 & 11.55 \\
\hline $\begin{array}{l}\text { Ib fuel N/10 } \\
\text { Btu }\end{array}$ & 1.11 & 1.05 & 0.75 & 0.77 & 1.19 & 0.99 \\
\hline VM/FC Ratio & 0.62 & 0.73 & 0.84 & 1.08 & 6.05 & 5.35 \\
\hline $\begin{array}{l}\mathrm{Cl} / \mathrm{S} \text { molar } \\
\text { ratio }\end{array}$ & 0.12 & 0.10 & 0.05 & 0.01 & 0.21 & 1.17 \\
\hline
\end{tabular}

Source: Tillman et al. (2009)

\section{Biomass co-firing challenges and hurdles}

Many challenges exist in co-combustion of biomass and coal. To list some of the important ones a) fuel preparation, b) handling, c) storage issues, d) milling, e) feeding, f) different combustion behavior, g) possible changes in overall efficiency, h) deposit formation (slagging and fouling), i) agglomeration and sintering, j) corrosion and/or erosion and consequently changes in life-time of equipment, k) ash utilization issues and I) overall economics (Baxter, 2005; Karki et al., 2004; EUBION and Jarvinen and Alakangas, 2001). 
Table 11. Physical and chemical characteristics of biomass feedstocks and their effects on cofiring

\begin{tabular}{|c|c|c|}
\hline & Properties & Effects \\
\hline \multirow{4}{*}{$\frac{\bar{d}}{\frac{0}{n}}$} & Moisture content & $\begin{array}{l}\text { Storage durability } \\
\text { Dry-matter losses } \\
\text { Low NCV } \\
\text { Self ignition }\end{array}$ \\
\hline & Bulk density & Fuel logistics (storage, transport, handling) costs \\
\hline & Ash content & $\begin{array}{l}\text { Dust, particle emissions } \\
\text { Ash utilization/disposal costs }\end{array}$ \\
\hline & $\begin{array}{l}\text { Particle dimension and size } \\
\text { distribution }\end{array}$ & $\begin{array}{l}\text { Determines fuel feeding system } \\
\text { Determines combustion technology } \\
\text { Drying properties } \\
\text { Dust formation } \\
\text { Operational safety during fuel conveying }\end{array}$ \\
\hline \multirow{13}{*}{ 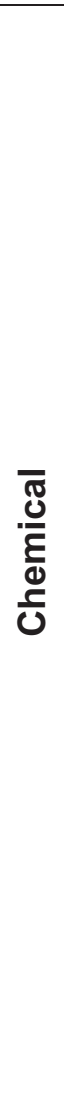 } & Carbon C & GCV (positive) \\
\hline & Hydrogen $\mathrm{H}$ & GCV (positive) \\
\hline & Oxygen O & GCV (negative) \\
\hline & Chlorine $\mathrm{Cl}$ & Corrosion \\
\hline & Nitrogen $\mathrm{N}$ & $\mathrm{NOx}, \mathrm{N} 2 \mathrm{O}, \mathrm{HCN}$ emissions \\
\hline & Sulfur S & SOx emissions, corrosion \\
\hline & Fluor $\mathrm{F}$ & $\begin{array}{l}\text { HF emissions } \\
\text { Corrosion }\end{array}$ \\
\hline & Potassium, $\mathrm{K}$ & $\begin{array}{l}\text { Corrosion (heat exchangers, superheaters) } \\
\text { Lowering of ash melting temperatures } \\
\text { Aerosol formation } \\
\text { Ash utilization (plant nutrient) }\end{array}$ \\
\hline & Sodium, $\mathrm{Na}$ & $\begin{array}{l}\text { Corrosion (heat exchangers, superheaters) } \\
\text { Lowering ash melting temperatures } \\
\text { Aerosol formation }\end{array}$ \\
\hline & Magnesium, Mg & $\begin{array}{l}\text { Increase of ash melting temperature } \\
\text { Ash utilization (plant nutrient) }\end{array}$ \\
\hline & Calcium, $\mathrm{Ca}$ & $\begin{array}{l}\text { Increase of ash melting temperature } \\
\text { Ash utilization (plant nutrient) }\end{array}$ \\
\hline & Phosphorus, $\mathrm{P}$ & $\begin{array}{l}\text { Increase in ash meting point } \\
\text { Ash utilization (plant nutrient) }\end{array}$ \\
\hline & Heavy metals & $\begin{array}{l}\text { Emissions of pollutants } \\
\text { Ash utilization and disposal issues } \\
\text { Aerosol formation }\end{array}$ \\
\hline
\end{tabular}

Source: European Biomass Association et al. (2000) and Loo van and Koppejan (2004)

Note: GCV: Gross calorific value, NCV: Net calorific value

Existing coal mills have a certain capacity, however, the grindability of biomass can limit the amount of biomass that can be co-milled with coal in existing mills, and consequently co-fired. Moreover, coal mills or pulverizers cannot process certain types of biomass, due to its fibrous nature. These problems are often not faced in indirect or parallel co-firing configurations, as the biomass is milled and delivered to the boiler by an independent line (such dedicated line can also be introduced to direct co-firing system). Mixtures of fuels with different combustion behaviors such as blends of wood fuels with straw cannot be combusted together in grate 
furnaces, whereas fluidized bed combustion systems are more fuel flexible, but have problems related to bed agglomeration.

Herbaceous biomass is difficult to size in coal pulverizers or mills as it has high chlorine and alkali content, which creates corrosion problems and deposit formation, whereas wood biomass which contains less ash and alkali components, makes it more suitable. According to CEN-335Solid biofuels, Fuel Specifications and Classes (2003) most of the challenges that co-firing poses to boiler operation originate from fuel properties and can be summarized as follows (Demirbas, 2003).

$>$ Pyrolysis starts earlier for biomass than for coal

$>$ Volatile matter content of biomass is higher than in coal

$>$ Fractional heat contribution by volatile substances in biomass is approximately $70 \%$ compared with $30-40 \%$ in coal

$>$ Specific heating value $[\mathrm{kJ} / \mathrm{kg}]$ of volatiles is lower for biomass compared with coal

$>$ Biomass char has more oxygen compared with coal and it is more porous and reactive

$>$ Biomass ash is more alkaline in nature, which may aggravate the fouling problems

$>$ Biomass can have high chlorine content.

Corrosion of the boilers surfaces is one of the major issues when co-firing biomass with coal. The most commonly identified corrosion mechanism is the reaction of chlorine with alkali metals (potassium and sodium). Chlorides form the most stable alkali-bearing species in the gas phase, as $\mathrm{KCl}$ and $\mathrm{NaCl}$. Potassium chloride is most significant when co-firing or firing biomass alone. These compounds can deposit on pendant tubes and other heat transfer surfaces (Tillman et al., 2009).

Issues related to ash gains importance when biomass is considered for combustion along with coal in co-firing plants. Ash contents of different biomass fuels can vary significantly (Table 12). Straw and other herbaceous fuels like Miscanthus or grass have higher ash contents than wood because they uptake relatively more nutrients during growth. In case of wood fuels, the bark content in the fuel has an influence on the ash content, as bark has higher ash content and higher level of mineral impurities such as sand and soil (Loo van and Koppejan 2004).

Table 12. Ash content of different biomass fuels and coal

\begin{tabular}{ll}
\hline Biomass fuel & Ash content (\% wt, d.b) \\
\hline Bark & $5-8$ \\
Wood chips with bark (forest) & $1-2.5$ \\
Wood chips without bark (industrial) & $0.8-1.4$ \\
Sawdust & $0.5-1.1$ \\
Waste wood & $3-12$ \\
Starch and cereals & $4-12$ \\
Miscanthus & $2-8$ \\
Coal & $5-45(8.5-10.5$ on average) \\
\hline
\end{tabular}

Source: Loo van and Koppejan 2004; Kavalov and Peteves 2004; EUBION; Foster et al. (2004)

Direct co-firing of biomass and coal produces mixed biomass and coal ash, whereas parallel cofiring and indirect co-firing can produce separate biomass and coal ashes. The utilization options for the ash produced (single coal, single biomass, and mixed biomass with coal) are important from environmental and performance of co-firing systems. 


\section{Coal ash utilization}

The ash produced during firing of coal (boiler slag, fly ash and bottom ash) is utilized in the construction industry and underground mining, restoration of open cast mines, pits and quarries.

Biomass ash utilization

Potentially, the ash originating from combustion or gasification of biomass can be used as fertilizers or fertilizer production as they are rich in $\mathrm{Mg}$ and $\mathrm{Ca}$. Lack of nitrogen and soluble phosphorous limits its application for fertilizer. Direct utilization of biomass ash in building applications might be possible only for some types of bottom ash; or it might be used as raw material in the production of building materials. Presently, several research activities are characterizing biomass ash and assessing the possibilities for its utilization. Fly ash from fluidized bed gasification of biomass can be used as fuel for power generation as they have high energy content. These ash have high calorific value due to high amounts of unburned carbon and are hydrophobic According to the estimates in utilization of ash as a fuel is the best option for carbon-rich ash, from the economical point of view. Ash can be reused as fuel directly in a form of a fine powder (in PF boiler), or compacted by pelletisation or granulation. Ash in forms of pellets, briquettes or granules has the following advantages: their volume is reduced by factor 46 , they can be stored in ambient air, and the health and safety risks (e.g. dust explosion) are reduced. To make this application successful, consistency and quality of ash is a key factor. Also ash needs to be provided in quantities high enough, to boost interest and development of ash utilization options (Broek van der et al 2002).

\section{Biomass Pretreatment methods to reduce co-firing issues}

Different pretreatment methods include a) washing/leaching, b) grinding, c) pelletization, d) briquetting, e)_torrefaction, and f) steam explosion. Biomass pretreatment is carried out for the following reasons (Loo van and Koppejan, 2004; IEA Bioenergy; ECN, 2004).

$>$ Biomass obtained from different sources often does not match with the narrow fuel specifications of feeding systems and the conversion processes considered.

$>$ Reduce the cost of handling, storage and transportation and to improve transport and storage characteristics.

$>$ Reduce the need to invest in complex and expensive combustion or gasification installations.

$>$ Reduce the plant's investment, maintenance and personnel costs by using homogenous fuel that is suitable for an automatic fuel feeding combustion system.

$>$ Biomass properties achieved due to pre-treatment can reduce certain problems related to co-firing like a) problems associated with biomass supply chain (e.g. the costs of transportation of pelletized or briquetted biomass are lower than those of untreated biomass) b) operational constraints (certain forms of pre-treatment allow for utilization of coal infrastructure for feeding, milling etc. of biomass, without their costly modifications or installation of separate processing lines for biomass) and c) technical constraints (e.g. reduction of corrosion due to biomass washing).

\section{Washing/Leaching}

The potential problems with biomass co-firing with coal include ash deposit, slag formation, corrosion, sintering and agglomeration and problems related to chemical composition due to presence of $\mathrm{Cl}, \mathrm{Na}$ and $\mathrm{K}$. The alkali compounds in the biomass can be reduced by methods like washing and leaching which help to remove troublesome elements. Additives such as dolomite and kaolin are capable of reducing sintering problems by raising the melting point of 
ash. Also vaporization of alkali compounds can be reduced by a decrease in process temperature (Davidson 2002). Washing of herbaceous biomass is very important due to high ash content (Jenkins, 1996; Davidson, 2001; Jensen, 2001). The removal of alkali metals, chlorine and sulfur can be beneficial in increasing the fusion temperatures of straw ash (Jenkins, 1996).

In general washing and leaching can occur with water, acid, or ammonia. (Davidson, 2001) Around $90 \%$ of alkali in biomass is present in water-soluble or ion-exchangeable form, and is susceptible to vaporization during heating (Davidson, 2001). Typical ash-forming components that are leached out by water include alkali sulphates, carbonates and chlorides (EUBION). Elements leached out by ammonia are organically associated, such as $\mathrm{Mg}, \mathrm{Ca}$ as well as $\mathrm{K}$ and $\mathrm{Na}$, whereas $\mathrm{HCl}$ leaches the carbonates and sulphates of alkaline earth and other metals. Silicates and other minerals remain in the insoluble residue (EUBION). If biomass washing can effectively reduce problems caused by alkali components in biomass, largescale washing of problematic fuels prior to combustion may be economically feasible in industrial conversion systems (Davidson, 2001). Reduction of alkali compounds in biomass feedstock before co-firing can save cost involved in maintenance (e.g. superheaters would become more durable for longer periods) (CORDIS, 2005).

\section{Grinding}

Preparation of biomass for co-firing in a boiler requires reducing the material to a smaller size (Task $3.4,2001$ ). It is usually not practical and not necessary to bring biomass feedstock to the same size or shape as coal, however large and aspherical biomass particles cause challenges for fuel conversion efficiency (in case of coal such sizes would cause an incomplete combustion, in case of biomass this effect is mitigated due to its highly volatile character) (Wieck-Hansen and Sander, 2003). Size reduction of biomass can be carried out by the following methods

$>$ Grinding or hammer mills can be used to produce particle sizes below $5 \mathrm{~mm}$.

$>$ drum chippers and disc chippers are used for particle sizes in the range of $5-50 \mathrm{~mm}$

$>$ Chunking to particle size of 5-25 cm-the particle sizes produced by a chunker vary more that those produced by chippers, however the advantage of a chunker is its low power consumption.

\section{Pelletizing}

Pelletizing is a compacting process that produces homogenous fuel with a high energy density in cylindrical shapes with dimension of 6-8 mm diameter (Loo van and Koppejan, 2004). Currently, pellets are the most appropriate biomass-derived fuel to be utilized in coal-fired plants (Bergman et al., 2005). Pelletizing of the biomass addresses the low bulk density problems associated with biomass which significantly impacts the transportation costs and also can restrict the co-firing ratio due to limited capacity of boiler input systems. Pelletizing can be applied to various biomass like woody as well as herbaceous. Additionally, the properties of pellets make it easier to grind the feedstock, handle it, and feed into the boiler. The properties of biomass pellets are indicated in Table 13. The process of pelletizing includes drying, milling, conditioning, actual pelletizing and cooling and separation of fines ((Loo van and Koppejan, 2004). 
Table 13. Properties of densified biomass

\begin{tabular}{lll}
\hline & Wood pressing & Bark pressings \\
\hline Moisture content [(wt\% (w.b)] & $<12$ & $<18$ \\
Ash content [(wt\% (d.b)] & $<0.5$ & $<6$ \\
NCV [MJ/kg (d.b.)] & $>18$ & $>18$ \\
S content [wt.\% (d.b.)] & $<0.04$ & $<0.08$ \\
N content [wt.\% (d.b.)] & $<0.3$ & $<0.6$ \\
Cl content [wt.\% (d.b.)] & $<0.02$ & $<0.04$ \\
\hline
\end{tabular}

Source: (Loo van and Koppejan, 2004)

Challenges using pellets in co-firing plants are

$>$ Dust generation during uploading and unloading of pellets as they can reduce to fines due to mechanical damaging (easily disintegrate and cause dust and handling problems).

$>$ Pellets are hydrophilic in nature which makes them difficult to handle when wet. They tend to absorb moisture from surroundings which make them swell; loose shape and consistency and create handling problems.

\section{Briquetting}

Co-firing of coal with biomass briquettes is an interesting option as the properties allow for using coal infrastructure (transport, storage, feeding) without modification of the system. The advantages of briquetting of agricultural residues for boiler applications are (Purohit et al., 2005):

Rate of combustion can be comparable to that of coal

$>$ Uniform combustion can be achieved

> Particulate emissions can be reduced

$>$ Storage properties are improved

> Transportation, storage and feeding are more efficient.

Briquettes can be made from biomass, or blends of biomass and coal-dust (Yaman et al., 2001). The typical diameter of briquettes is $30-100 \mathrm{~mm}$ (Loo van and Koppejan 2004). Briquettes have density of $800-1200 \mathrm{~kg} / \mathrm{m} 3$ compared to $60-180 \mathrm{~kg} / \mathrm{m} 3$ of loose biomass. The major limitation of the biomass briquettes is uptake of moisture during storage which can lead to increase in biological degradation and loss of dimensional stability.

\section{Torrefaction}

Torrefaction is treating the biomass thermo-chemically in the absence of oxygen at temperatures between $200-300^{\circ} \mathrm{C}$ for residence times of $30-60 \mathrm{~min}$. During this process the biomass partially decomposes giving off volatiles and giving the remaining solid as a final product (sometimes referred to as char) (Bergman, 2005). Torrefaction is a promising technique which can make biomass properties comparable to coal and makes biomass feedstocks favorable to combustion and gasification. Some of the advantages of torrefaction are

$>$ Increases the heating value per unit weight

$>$ Makes biomass hydrophobic in nature

$>$ Improves the grinding properties

$>$ Increases the uniformity in the feedstocks

$>$ Increases the binding properties as more lignin is available for binding during pelletizing

$>$ Can help to achieve a uniform feedstock 
Torrefaction can help to reduce some of the constraints biomass has in relation to co-firing with coal. Size reduction is a major issue due to fibrous nature of the biomass, torrefaction makes the biomass flaky and crisp which helps in size reduction and reduces the energy required by un to $70-90 \%$ (similar to bituminous coal) (Bergman, 2005). It improves the storage and feeding characteristics as the biomass is hydrophobic and does not absorb moisture from environment. It also reduces the dry matter loss during storage and helps to maintain quality. The research carried out on co-firing of torrefied wood up to $9 \%$ (energy basis), mixed with coal has led to the conclusion that there is still enough room for increasing the co-firing ratio (pulverizer's limits were not reached), and co-firing of torrefied wood can be a viable feedstock option for direct cofiring of biomass with coal (Weststeyn, 2004). The drawback of torrefaction is low volumetric energy density (volume of the torrefied biomass is around $180-300 \mathrm{~kg} / \mathrm{m}^{3}$ ). The low volumetric energy density problems can be overcome by pelletizing the torrefied materials. Torrefaction and pelletisation can be complementary as they address each other's limitations. Physical properties of wood chips and torrefied wood pellets are given in Table 14. The chemical composition of different torrefied biomass material is given in Table 15.

Table 14. Physical properties of wood chips, regular and torrefied pellets

\begin{tabular}{llll}
\hline Physical Property & Wood chips & Wood pellets & $\begin{array}{l}\text { Torrefied } \\
\text { wood pellets }\end{array}$ \\
\hline Moisture content $(\%)$ & 35 & $6-10 \%$ & $1-5 \%$ \\
Calorific Value $(\mathrm{MJ} / \mathrm{kg})$ & 10.5 & 16 & 21 \\
Bulk density $\left(\mathrm{kg} / \mathrm{m}^{3}\right)$ & $300-500$ & $600-650$ & $750-800$ \\
Energy bulk density & 5.8 & 9 & 16.7 \\
Hygroscopic nature & Wets & Wets & Hydrophobic \\
Behaviour in storage & Gets mouldy & Deteriorates and gets & Stable \\
& Dry matter loss & mouldy & \\
\hline
\end{tabular}

Source: Mitchell et al. (2007)

Table 15. Ultimate analysis, HHV (dry ash free basis), and moisture content of untreated and torrefied biomass

\begin{tabular}{|c|c|c|c|c|c|}
\hline \multirow{2}{*}{ Reed Canary Grass } & \multirow[t]{2}{*}{ Raw } & \multicolumn{4}{|c|}{ Torrefaction temperature ${ }^{\circ} \mathrm{K}$} \\
\hline & & 503 & 523 & 543 & 563 \\
\hline C (\%) & 48.6 & 49.3 & 50.3 & 52.2 & 54.3 \\
\hline$H(\%)$ & 6.8 & 6.5 & 6.3 & 6.0 & 6.1 \\
\hline $\mathrm{N}(\%)$ & 0.3 & 0.1 & 0.0 & 0.1 & 0.1 \\
\hline $\mathrm{O}(\%)$ & 37.3 & & 37.0 & 37.3 & 36.3 \\
\hline Moisture (\%) & 4.7 & 2.5 & 1.9 & 1.3 & 1.2 \\
\hline $\mathrm{CV}(\mathrm{kJ} / \mathrm{kg})$ & 19,500 & & 20,000 & 20,800 & 21,800 \\
\hline \multicolumn{6}{|l|}{ Wheat straw } \\
\hline C (\%) & 47.3 & 48.7 & 49.6 & 51.9 & 5.6 \\
\hline $\mathrm{H}(\%)$ & 6.8 & 6.3 & 6.1 & 5.9 & 1.0 \\
\hline $\mathrm{N}(\%)$ & 0.8 & 0.7 & 0.9 & 0.8 & 27.6 \\
\hline $\mathrm{O}(\%)$ & 37.7 & & 35.6 & 33.2 & 0.8 \\
\hline Moisture (\%) & 4.1 & 1.5 & 0.9 & 0.3 & 0.8 \\
\hline CV $(\mathrm{kJ} / \mathrm{kg})$ & 18,900 & 19,400 & 19,800 & 20,700 & 22,600 \\
\hline \multicolumn{6}{|l|}{ Willow } \\
\hline $\mathrm{C}(\%)$ & 49.9 & 50.7 & 51.7 & 53.4 & 54.7 \\
\hline $\mathrm{H}(\%)$ & 6.5 & 6.2 & 6.1 & 6.1 & 6.0 \\
\hline $\mathrm{N}(\%)$ & 0.2 & 0.2 & 0.2 & 0.2 & 0.1 \\
\hline
\end{tabular}




\begin{tabular}{llllll}
\hline O (\%) & 39.9 & 39.5 & 38.7 & 37.2 & 36.4 \\
Moisture (\%) & 2.8 & 0.5 & 0.1 & 0.1 & 0.0 \\
CV (kJ/kg) & 20,000 & 20,600 & 20,600 & 21,400 & 21,900 \\
\hline
\end{tabular}

Source: Bridgeman et al. (2008)

\section{Pyrolysis}

Fast or flash pyrolysis is an option for directly converting to a liquid product (pyrolysis oil) from biomass through thermal decomposition at temperatures of $450-550^{\circ} \mathrm{C}$. Pyrolysis oil consists of about $70 \%$ oxygenated organics and $30 \%$ water (weight basis). The yield efficiency of the pyrolysis oil production is on average about $70 \%$, depending on the feedstock, process configuration, and conditions. The volumetric energy content of pyrolysis oil is about $19 \mathrm{GJ} / \mathrm{m}^{3}$, which is much higher than that of biomass logs $(6 \mathrm{GJ} / \mathrm{m} 3)$. Thus, the transportation costs, which are a major factor that influences the overall cost efficiency of biomass utilization in energy systems, are reduced significantly. The application of pyrolysed biomass for co-firing can be sometimes challenging, as the liquid products obtained by means of pyrolysis are rich in water that is detrimental for ignition (Yaman 2000). Table 16 indicates the biomass pyrolysis products.

Table 16: Biomass pyrolysis products

\begin{tabular}{llll}
\hline Process & Products & & \\
\hline $\begin{array}{l}\text { Fast pyrolysis (moderate temperature short residence } \\
\text { time) }\end{array}$ & Liquids (\%) & Char (\%) & Gases (\%) \\
$\begin{array}{l}\text { Carbonization (Low temperature and long residence } \\
\text { time) }\end{array}$ & 30 & 12 & 13 \\
$\begin{array}{l}\text { Gasification (high temperature long residence time) } \\
\text { S }\end{array}$ & 5 & 35 & 35 \\
\hline
\end{tabular}

Source: Stefan Czernik, NREL

Summary of hurdles required for biomass for co-firing in cogeneration plant are given in Table 17. Table 18 indicates the summary of the advantages of biomass pretreatment and further challenges associated. 
Table 17. Summary of the hurdles for biomass-coal co-firing

Hurdles Required Attributes Solutions

\begin{tabular}{|c|c|c|c|c|}
\hline $\begin{array}{l}\text { Feed Milling, } \\
\text { Entrainment, } \\
\text { Classification }\end{array}$ & $\begin{array}{l}\checkmark \\
\checkmark \\
\checkmark \\
\checkmark \\
\checkmark\end{array}$ & $\begin{array}{l}\text { Less hydrophillic } \\
\text { Low in fiber } \\
\text { Low in moisture and oily residues } \\
\text { Low friability } \\
\text { Particle density equivalence (particle } \\
\text { size/momentum) }\end{array}$ & $>$ & $\begin{array}{l}\text { Torrefaction reduces moisture } \\
\text { and oils, reduces fibers; } \\
\text { Pelletization increases density } \\
\text { and particle hardness }\end{array}$ \\
\hline Feed System & $\begin{array}{l}\checkmark \\
\checkmark \\
\checkmark \\
\checkmark \\
\end{array}$ & $\begin{array}{l}\text { Dense-phase particle pneumatic transport } \\
\text { Uniform particle size } \\
\text { Low explosivity index } \\
\text { Particle density equivalence }\end{array}$ & $>$ & Torrefaction \& pelletization (ibid) \\
\hline Burner Performance & $\begin{array}{l} \\
\checkmark \\
\checkmark \\
\checkmark\end{array}$ & $\begin{array}{l}\text { Flame properties match fuel-oxidant mixing and } \\
\text { reactions design parameters } \\
\text { Volatiles behavior similarity } \\
\text { Soot formation \& radiation similarity } \\
\text { Acceptable pollutant formation / control }\end{array}$ & $>$ & $\begin{array}{l}\text { Torrefaction to adjust fuel heat } \\
\text { content } \\
\text { Feedstock selection (nitrogen, } \\
\text { sulfur, chlorine, etc) }\end{array}$ \\
\hline Slagging / Fly Ash & $\begin{array}{l}\checkmark \\
\checkmark \\
\checkmark\end{array}$ & $\begin{array}{l}\text { Mineral composition affecting slag formation } \\
\text { temperature, viscosity, and corrosivity } \\
\text { Elemental ash composition } \\
\text { Softening / ash fusion temperature }\end{array}$ & $\vec{D}$ & $\begin{array}{l}\text { Washing and leaching } \\
\text { Feedstock selection / blending }\end{array}$ \\
\hline $\begin{array}{l}\text { Post Combustion } \\
\text { Processes }\end{array}$ & $\begin{array}{l}\checkmark \\
\checkmark \\
\checkmark\end{array}$ & $\begin{array}{l}\text { Minimal impact on SCR catalyst bed poisoning } \\
\text { Minimal impact on precipitators and scrubbers } \\
\text { Minimal impact on baghouse particle collectors }\end{array}$ & $>$ & $\begin{array}{l}\text { Managing fuel properties by pre- } \\
\text { treatment processes- i.e., } \\
\text { torrefaction, washing/leaching } \\
\text { Feedstock selection / blending }\end{array}$ \\
\hline
\end{tabular}


Table 18. Biomass pretreatment methods, advantages and challenges

\section{Pretreatment Advantages \\ Challenges}

method

$\checkmark \quad$ Basic pre-treatment bringing the feedstock to the

Sizing size required by boiler specifications

chipping,

chunking and

milling)

$>$ Storage of sized biomass can increase microbiological activity and dry matter losses

$>$ Due to microbiological activity, biomass storage can be a source of significant GHG emissions ( $\mathrm{CH} 4, \mathrm{~N} 2 \mathrm{O})$.

$>$ Sizing can be problematic due to non-friable character of biomass

\begin{tabular}{|c|c|c|c|c|}
\hline Drying & $\begin{array}{l}\checkmark \\
\checkmark \\
\checkmark \\
\checkmark\end{array}$ & $\begin{array}{l}\text { Reduces dry matter (energy) losses of biomass } \\
\text { during storage } \\
\text { Reduces the risk of biomass decomposition, } \\
\text { selfignition } \\
\text { Risk, and problems with fungi development during } \\
\text { storage } \\
\text { Increases potential energy input for steam } \\
\text { generation }\end{array}$ & $>$ & $\begin{array}{l}\text { Natural drying is commonly applied, however } \\
\text { has a disadvantage of unforeseeable } \\
\text { weather conditions } \\
\text { Drying in dryers require sized biomass } \\
\text { which can be problematic due to non-friable } \\
\text { character of biomass }\end{array}$ \\
\hline Pelletizing & $\begin{array}{l}\checkmark \\
\checkmark \\
\checkmark \\
\\
\checkmark \\
\checkmark \\
\\
\checkmark \\
\checkmark\end{array}$ & $\begin{array}{l}\text { Higher energy density, with benefits for } \\
\text { transportation costs } \\
\text { Possibility for utilization of coal infrastructure for } \\
\text { feeding and milling (permits automatic handling } \\
\text { and feeding) } \\
\text { Easier grinding } \\
\text { Increased possible co-firing ratio (if constrained by } \\
\text { boiler capacity and low bulk density of untreated } \\
\text { biomass) } \\
\text { Less storage space required } \\
\text { Dry feedstock (better storage properties, reduced } \\
\text { health risks, reduced energy losses, higher calorific } \\
\text { value) }\end{array}$ & $>$ & $\begin{array}{l}\text { Pellets, despite their benefits, can be } \\
\text { sensitive to mechanical damaging and can } \\
\text { absorb moisture and swell, loose shape and } \\
\text { consistency. } \\
\text { They require specific storage environment for } \\
\text { safe and efficient storage. }\end{array}$ \\
\hline Briquetting & $\begin{array}{l}\checkmark \\
\checkmark \\
\checkmark \\
\checkmark\end{array}$ & $\begin{array}{l}\text { Higher energy density, possibility for more efficient } \\
\text { transport } \\
\text { Possibility for utilization of coal infrastructure for } \\
\text { storage, milling, and feeding } \\
\text { Less storage space required } \\
\text { Possibility of spontaneous combustion during } \\
\text { storage is reduced }\end{array}$ & $>$ & $\begin{array}{l}\text { Easy moisture uptake potentially leading to } \\
\text { biological degradation and loss of structure } \\
\text { (similarly to } \\
\text { pellets), therefore briquettes require special } \\
\text { storage conditions. } \\
\text { Hydrophobic agents can be added to } \\
\text { briquetting process, but increase their costs }\end{array}$ \\
\hline
\end{tabular}




\begin{tabular}{|c|c|c|c|c|}
\hline & $\checkmark$ & Rate of combustion comparable with coal & & significantly. \\
\hline $\begin{array}{l}\text { Washing } \\
\text { /leaching }\end{array}$ & $\begin{array}{l} \\
\checkmark \\
\checkmark \\
\checkmark\end{array}$ & $\begin{array}{l}\text { Reduction of corrosion } \\
\text { Reduction of slagging, fouling (ash deposition), } \\
\text { sintering and agglomeration of the bed } \\
\text { Reduces the wearing-out of equipment,and } \\
\text { decreases the risk of shut-down of the system for } \\
\text { related maintenance } \\
\text { Washing is especially important in case of } \\
\text { herbaceous feedstocks. }\end{array}$ & $>$ & $\begin{array}{l}\text { Moisture content of biomass is increased } \\
\text { after washing }\end{array}$ \\
\hline Torrefaction & $\begin{array}{l} \\
\checkmark \\
\checkmark \\
\checkmark \\
\checkmark\end{array}$ & $\begin{array}{l}\text { Possibility for utilization of coal infrastructure for } \\
\text { feeding and milling } \\
\text { Improved hydrophobic nature - easy and safe } \\
\text { storage, biological degradation almost impossible } \\
\text { Improved grinding properties resulting in reduction } \\
\text { of power consumption during sizing } \\
\text { Increased uniformity and durability }\end{array}$ & $>$ & $\begin{array}{l}\text { Torrefied biomass has low volumetric energy } \\
\text { density (biomass volume after torrefaction is } \\
\text { reduced only slightly, ranging from } 180- \\
300 \mathrm{~kg} / \mathrm{m}^{3}\end{array}$ \\
\hline TOP process & $\begin{array}{l}\checkmark \\
\checkmark \\
\checkmark\end{array}$ & $\begin{array}{l}\text { Combines the advantages of torrefaction and } \\
\text { pelletizing, while addressing the challenges related } \\
\text { to both. } \\
\text { Torrefaction could solve the drawbacks } \\
\text { encountered with the durability and biological } \\
\text { degradation of pellets. In return, pelletisation of } \\
\text { torrefied biomass offers solution to its low } \\
\text { volumetric energy density. } \\
\text { After torrefaction, the high energy-consumption for } \\
\text { size reduction and densification is avoided, and the } \\
\text { desired production capacity can be established } \\
\text { with smaller equipment. } \\
\text { Higher energy density, resulting in decreased } \\
\text { transportation costs. } \\
\text { Easy utilization of coal infrastructure for feeding } \\
\text { and milling } \\
\text { Less storage space required }\end{array}$ & $\nabla$ & $\begin{array}{l}\text { Does not address the problems related to } \\
\text { biomass chemical properties i.e. corrosion, } \\
\text { slagging, fouling, sintering, or agglomeration } \\
\text { of the co-firing systems. }\end{array}$ \\
\hline
\end{tabular}

Source: Maciejewska et al. (2006) 


\section{Conclusions}

$>$ The main constraints for co-firing biomass with coal, especially in direct co-firing operations which is considered as the most common method, are handling, storage, milling and feeding problems, deposit formation (slagging and fouling), agglomeration, corrosion and/or erosion, and ash utilization issues.

$>$ Some of the methods for overcoming the hurdles of co-firing biomass with coal are taking preventive measure in the downstream like cleaning of deposits by soot blowing or exchange of agglomerated bed material, adding chemicals to reduce corrosion and increase the ash melting point in order to avoid agglomeration and deposit formation, introducing dedicated biomass infrastructure (e.g. feeding, milling, storage, conveying) to the existing coal system, and more expensive alternative (in terms of investment costs) is introducing more advanced co-firing modes such as parallel co-firing or indirect cofiring, where not only fuel preparation and feeding lines, but also conversion units for biomass and coal are independent.

$>$ Co-firing hurdles in terms of physical, chemical and storage properties of biomass can be reduced by pre-treatment.

$>$ Pre-treatment methods like size reduction, washing, pelletizing, briquetting and torrefaction can help to modify the biomass properties and make them more suitable for co-firing.

$>$ Torrefaction of biomass makes it to behave more like coal and will help overcome the grinding issues associated with the fibrous nature of biomass and moisture uptake during storage. The physical and chemical properties of torrefied \& densified biomass are comparable with some coals like N. Dakota Lignite and Powder River Basin coal (Black Thunder) available in USA.

> Torrefied biomass has less hydrogen, oxygen and volatile matter and higher carbon which make it more suitable for co-firing with coal.

> Densification of torrefied biomass material can be the best option in terms of modifying physical properties, chemical composition and storage behavior for co-firing with coal.

$>$ The alkali compounds in the biomass can be reduced by methods like washing and leaching. Reduction of alkali compounds in biomass feedstock before co-firing can save cost involved in maintenance of co-firing systems.

$>$ More research has to be carried out to understand the elemental ash composition of the torrefied biomass at different torrefaction temperature, residence time and biomass species.

An interesting option is pyrolysis of biomass into pyrolysis oil, however this option cannot be applied in direct co-firing systems since the liquid form of the feedstock requires a separate conversion unit as well as dedicated transport, storage, feeding etc. systems. 


\section{ACKNOWLEDGEMENTS}

This work is supported by the U.S. Department of Energy, under DOE Idaho Operations Office Contract DE-AC07-05ID14517. Accordingly, The U. S. Government retains and the publisher, by accepting the article for publication, acknowledges that the U. S. Government retains a nonexclusive, paid-up, irrevocable, world-wide license to publish or reproduce the published form of this manuscript, or allow others to do so, for U. S. Government purposes.

\section{U.S. DEPARTMENT OF ENERGY DISCLAIMER}

This information was prepared as an account of work sponsored by an agency of the U.S. Government. Neither the U.S. Government nor any agency thereof, nor any of their employees, makes any warranty, express or implied, or assumes any legal liability or responsibility for the accuracy, completeness, or usefulness of any information, apparatus, product, or process disclosed, or represents that is use would not infringe privately owned rights. References herein to any specific commercial product, process, or service by trade name, trademark, manufacturer, or otherwise, does not necessarily constitute or imply its endorsement, recommendation, or favoring by the U.S. Government or any agency thereof. The views and opinions of authors expressed herein do not necessarily state or reflect those of the U.S. Government or any agency thereof.

\section{References}

Bain, R. L., W. A. Amos, M. Downing, and R. L. Perlack. 2003. Biopower Technical Assessment: State of the Industry and Technology. National Renewable Energy Laboratory Technical Report NREL/TP-510-33123. Golden, Colo.: National Renewable Energy Laboratory, 2003.

Baxter, L. 2005. Biomass-coal co-combustion: opportunity for affordable renewable energy. Fuel 84, 1295-1302.

Bergman, P.C.A. 2005. Combined torrefaction and pelletisation, The TOP process, ECN-C-05073.

Bergman, P.C.A., A.R. Boersma, R.W.R. Zwart, and J.H.A. Kiel. 2005. Torrefaction for biomass co-firing in existing coal-fired power stations "BIOCOAL", ECN, ECN-C-05-013.

Biomass Energy Center (http://www.biomassenergycentre.org.uk) webpage accessed Aug, 2010.

Bridgeman, T.G., J.M. Jones, I. Shiel, and P.T. Williams. 2008. Torrefaction of reed canary grass, wheat straw and willow to enhance solid fuel qualities and combustion properties. Fuel 87, 844-856.

Broek van der R., Wijk van A. and Turkenburg W. 2002. Electricity from energy crops in different settings - a country comparison between Nicaragua, Ireland and the Netherlands. Biomass and Bioenergy 22, 79-98.

CORDIS. 2005. Solving corrosion issues in combustion biomass, http://icadc.cordis.lu/fepcgi/ srchidadb?CALLER=OFFR_TM_EN\&ACTION=D\&RCN=2243.

Davidsson, K.O., J.G. Koresgren., J.B.C. Pettersson, and U. Jaglid. 2002. The effects of fuel washing techniques on alkali release from biomass. Fuel 81, 137-142.

Demirbas, A. 2003. Sustainable cofiring of biomass with coal. Energy Conversion and Management. 44, 1465-1479. 
ECN, Biomass pre-treatment and feeding (2004).

EUBION (European Bioenergy Networks), ALTENER, Biomass co-firing-an efficient way to reduce greenhouse gas emissions (http://ec.europa.eu/old-address-ec.htm)

EUROPA, European Commission, http://europa.eu.int/comm/research/energy/nn/nn_rt/nn_rt_bm/article_1111_en

European Biomass Association et al. (2000). Woodpellets in Europe. State of the Art, Technologies, Activities, Markets. Thermie B DIS/2043/98-AT, Industrial Network on Wood Pellets, http://www.energyagency.at/ (en)/publ/pdf/pellets_net_en.pdf, 2000.

Evan E. H., and D. A. Tillman.1998. Biomass cofiring: status and prospects 1996. Fuel Processing Technology 54, . 127-142

Foster D.J., W.R. Livingston, J. Wells, J.Williamson, W.H. Gibb and D. Bailey. 2004. Particle Impact Erosion and Abrasion Wear - Predictive Methods and Remedial Measures. Report No. COAL R241 DTI/Pub URN 04/701.

Mohammad Z., M. Behdad, and T. F. Wall. 2006. Flow properties of biomass and coal blends. Fuel Processing Technology 87, $281-288$. 